\title{
Pengurangan Kadar HCN pada Umbi Gadung Menggunakan Variasi Abu Gosok dan Air Kapur
}

\author{
Zulhaq Dahri Siqhny $^{1}$, Elly Yuniarti Sani ${ }^{2}$, Ika Fitriana ${ }^{3}$ \\ ${ }^{1,2,3}$ Staff Pengajar Jurusan Teknologi Hasil Pertanian, Fakultas Teknologi Pertanian, Universitas \\ Semarang, Indonesia
}

DOI: http://dx.doi.org/10.26623/jtphp.v13i1.1845

\section{Info Artikel}

\section{Sejarah Jurnal:}

Disubmit 6 Juli 2020

Direvisi 26 Agustus 2020

Disetujui 10 September 2020

Keywords:

Gadung Tubers; HCN; Rubbing

Ash; Lime Water; Flour

\begin{abstract}
Abstrak
Salah Satu sumber pangan lokal yang belum banyak dimanfaatkan oleh masyarakat adalah Umbi gadung (Discorea hispida dennst.). Komposisi kimia dalam gadung tersusun dari protein $2,1 \%$, lemak $0,2 \%$, karbohidrat $23,2 \%$ dan air 73,5 \% serta kalsium besi 0,6 $\mathrm{mg} / 100 \mathrm{~g}, 20,0 \mathrm{mg} / 100 \mathrm{~g}$ dan fosfor $69,0 \mathrm{mg} / 100 \mathrm{~g}$. Masih tingginya kandungan nutrisi umbi gadung berpotensi menjadi sumber karbohidrat. Saat ini, pemanfaatan umbi gadung tekendala dalam hal kandungan asam sianida $(\mathrm{HCN})$ yang dapat mengakibatkan keracunan pada manusia maupun binatang. Sianida akan keluar jika bahan makanan dihancurkan, dikunyah dan mengalami pengirisan atau rusak. Kadar sianida dalam makanan jika melebihi dari $(<100 \mathrm{mg} / \mathrm{kg})$ dapat dikategorikan sangat beracun. Sedangkan kandungan sianida alami yang terdapat dalam umbi gadung secara teori berkisar antara $50-400 \mathrm{mg} / \mathrm{kg}$. Oleh karena itu, diperlukan suatu proses tertentu dan penelitian lebih lanjut agar nantinya umbi gadung dapat dimakan dengan aman. Salah satunya dengan penyerapan racun $\mathrm{HCN}$ menggunakan abu gosok dan air kapur. Dalam penelitian ini, didapatkan hasil terbaik perlakuan penyerapan kadar $\mathrm{HCN}$ pada variable kapur $15 \%$ dengan waktu perendaman selama 24 jam dapat diturunkan sebesar $84.15 \%$. Hal ini disebabkan karena larutan kapur dapat menurunkan $\mathrm{pH}$ (basa kuat) hingga menetralkan kandungan asam pada $\mathrm{HCN}$ dan merusak dinding sel sehingga mengalami irisan umbi gadung mengalami plasmolisis (pecahnya membran sel karena kekurangan air). Pada penelitian ini penggunaan bahan penyerap kapur lebih baik daripada bahan penyerap abu gosok, sehingga penggunaan kapur dalam penurunan kadar HCN paling baik. Selain itu, alternatif lain dalam pengolahan umbi gadung adalah dengan menjadikan tepung. Karena secara tidak langsung dapat memperpanjang umur simpan dikarenakan rendahnya kadar air yang terkandung. Manfaat lain penepungan adalah untuk mendiversifikasikan dan meningkatkan daya fleksibilitas tepung umbi gadung sebagai bahan baku olahan, keuntungan lainya jika dilakukan penepungan adalah mudahnya dalam pengemasan, dapat memperluas area pemasaran dan dapat meningkatkan harga dasar umbi gadung menjadi lebih bagus sehingga dapat berdampak positif kepada petani umbi gadung. Selain itu, kelebihan lainya adalah tepung umbi gadung nantinya juga dapat digunakan sebagai subtitusi tepung terigu dan dapat digunakan dalam berbagai bahan baku industri
\end{abstract}




\section{Abstract}

One of the local food sources that have not been widely used by the community is Gadung Tubers (Discorea hispida etc.). The chemical composition of gadung tubers is composed of $2.1 \%$ protein, $0.2 \%$ fat, $23.2 \%$ carbohydrates and $73.5 \%$ water and $0.6 \mathrm{mg} / 100 \mathrm{~g}$ iron calcium, $20.0 \mathrm{mg} / 100 \mathrm{~g}$ and 69.0 phosphorus. $\mathrm{mg} / 100 \mathrm{~g}$. The high nutritional content of gadung tubers has the potential to be a source of carbohydrates. Currently, the use of gadung bulbs is constrained in terms of cyanide acid (HCN) content which can cause poisoning in humans and animals. Cyanide will be released when food ingredients are crushed, chewed, and shredded or damaged. Cyanide content in food if it exceeds $(<100 \mathrm{mg} / \mathrm{kg})$ can be categorized as very toxic. Meanwhile, the natural cyanide content contained in gadung tubers, in theory, ranges from $50-400 \mathrm{mg} / \mathrm{kg}$. Therefore, a certain process and further research are needed so that later the gadung tubers can be eaten safely. One of them is the absorption of HCN toxins using rubbing ash and lime water. In this study, the best results obtained were the absorption of HCN levels in the lime variable 15\% with immersion time for 24 hours which can be reduced by $84.15 \%$. This is because the lime solution can lower the $p H$ (strong base) to neutralize the acid content in HCN and damage the cell walls so that the slices of gadung tubers experience plasmolysis (rupture of the cell membrane due to lack of water). In this study, the use of a lime-absorbing agent was better than that of scouring ash, so that the use of lime in reducing HCN levels was best. Besides, another alternative in the processing of gadung tubers is to make flour. Because it can indirectly extend the shelf life due to the low water content contained. Another benefit of flouring is to diversify and increase the flexibility of the gadung tuber flour as a raw material for processing, other advantages of doing flouring are easy packaging, can expand the marketing area, and can increase the base price of gadung tubers to be better so that it can have a positive impact on gadung tubers farmers. Besides, another advantage is that the gadung tubers flour can later be used as a substitute for wheat flour and can be used in various industrial raw materials.

\footnotetext{
\} \text { Alamat Korespondensi: Zulhaq Dahri Siqhny, Teknologi Hasi }

E-mail: zulhaqdahrisiqhny@usm.ac.id 


\section{PENDAHULUAN}

Umbi gadung (Discorea hispida dennst.) dikenal sebagai salah satu sumber pangan lokal yang yang pemanfaatannya masih belum optimal di masyarakat. Kandungan nilai gizi pada gadung dapat bersaing dengan jenis umbi-umbian local lainnya (Pratiwi, 2016). Umbi gadung termasuk umbi yang tinggi karbohidrat dan memiliki senyawa bioaktif diantaranya yaitu Polisakarida Larut Air (PLA), dioscorin dan diosgenin. Kandungan nutrisi dalam umbi gadung terdiri atas protein 2,1\%, lemak 0,2 $\%$, karbohidrat $23,2 \%$ dan air 73,5\% serta kalsium besi $0,6 \mathrm{mg} / 100 \mathrm{~g}, 20,0 \mathrm{mg} / 100 \mathrm{~g}$ dan fosfor 69,0 $\mathrm{mg} / 100 \mathrm{~g}$ (Wulandari et al., 2017; Luthfi et al., 2012). Masih tingginya kandungan nutrisi umbi gadung berpotensi menjadi sumber karbohidrat (Kumoro et al., 2011) dan sebagai alternative lain makanan pokok. Saat ini, pemanfaatan umbi gadung masih terkendala karena terdapatnya kandungan asam sianida ( $\mathrm{HCN})$ yang dapat mengakibatkan keracunan pada manusia maupun binatang (Pramitha \& Wulan, 2017). Sianida akan keluar jika bahan makanan dihancurkan, dikunyah dan mengalami pengirisan atau rusak (Hardjo, 2005). Selain itu, didalam umbi gadung juga terdapat banyak senyawa antinutrisi seperti histamin, saponin, dan glukosida sianogenik (Widiyanti \& Cahyo Kumoro, 2017). Pada penelitian yang dilakukan oleh Apriansyah et al., (2014) menunjukkan bahwa perlakuan perendaman dengan air kapur secara berulang-ulang selama 6 hari dapat menurunkan kadar sianida dari $22,50 \mathrm{mg} / \mathrm{kg}$ menjadi $3,13 \mathrm{mg} / \mathrm{kg}$. Pada penelitian Kumoro et al., (2011) dilakukan penurunan kadar sianida dengan pencucian dengan air mengalir (laju $3 \mathrm{~L} /$ menit) selama 3 jam dan dihasilkan penurunan kadar sianida sebesar 50,55\%. Menurut Sasongko, (2009) standar kadar HCN menurut FAO yang dapat aman dikonsumsi manusia adalah dibawah $10 \mathrm{ppm}$. Tingginya kandungan $\mathrm{HCN}$ yang berada pada umbi gadung dan banyak terdapat juga zat-zat gizi yang masih baik bagi tubuh, menyebabkan penelitian ini layak untuk dilakukan. Selain itu umbi gadung banyak belum banyak dimanfaatkan sebagai bahan olahan makanan, karena masih tingginya kandungan $\mathrm{HCN}$ yang tersimpan. Subtitusi tepung gadung dalam berbagai makanan olahan berbahan dasar tepung terigu dapat dilakukan. Oleh karena itu, masih sangat luas ruang lingkup penelitian yang dapat dilakukan. Salah satu uji yang akan peneliti lakukan adalah uji kadar sianida dengan menurunkan kadar $\mathrm{HCN}$ serendah mungkin menggunakan metode variasi air kapur dan abu gosok.

\section{METODE}

Penelitian ini bertujuan untuk mengurangi kadar sianida dalam umbi gadung melalui formulasi pretreatment secara kimia. Pada proses pretreatment dilakukan perendaman irisan umbi gadung dalam variasi kondisi operasi perendaman. Sebelum proses perendaman akan dilakukan proses penanganan umbi gadung seperti pembersihan, pengupasan, dan pemotongan. Penelitian dilakukan menggunakan Rancangan Acak Lengkap (RAL) dengan tiga level perlakuan yaitu waktu perendaman 6 jam, 12 jam dan 24 jam dengan konsentrasi 5\% jenis perendam kapur. Kemudian level selanjutnya perlakuan tingkat konsentrasi 5\%, 10\% dan 15\% dengan waktu 24 jam dengan variasi jenis bahan perendam. Level sealanjutnya adalah dengan memperlakukan variable dengan waktu perendaman 24 jam dan konstrasi $15 \%$ dengan variasi jenis perendam.

\section{Prosedur Pembuatan Tepung Gadung}

Umbi gadung dicuci hingga bersih, kemudian dikupas $\pm 0,5 \mathrm{~cm}$ dan di cuci kembali. Tahap selanjutnya dilakukan pengirisan dengan ketebalan $\pm 0,3 \mathrm{~cm}$ dan direndam dengan variasi abu gosok dan air kapur dengan lama perendaman 6, 12, dan 24 jam. Umbi gadung yang telah direndam kemudian ditiriskan dan dikeringkan dalam food dehydrator dengan suhu $\pm 40^{\circ} \mathrm{C}$ selama $\pm 12 \mathrm{jam}$. Kemudian ditepungkan dengan disk mill dan diayak dengan saringan 80 mesh.

\section{Prosedur Uji Kadar Sianida (HCN)}

Pengujian kadar sianida menggunakan instrument spektrofotometri. Pengujian dilakukan sebanyak tiga kali ulangan dan diambil nilai rata-ratanya, kemudian di hitung standar deviasinya. Pada prinsipnya, $\mathrm{HCN}$ dalam sampel diubah menjadi Cyanogen Chlorida $(\mathrm{CNCl})$ (gas yang sangat beracun) karena bereaksi dengan khloramin-T pada $\mathrm{pH}$ kurang dari 8 terhidrolisa menjadi cianat. Setelah bereaksi secara sempurna, $\mathrm{CNCl}$ membentuk warna merah biru dengan asam barbiturat dalam piridin dan warna yang terjadi dibaca pada Panjang gelombang $575 \mathrm{~nm}-582 \mathrm{~nm}(578$ nanometer). 


\section{Analisa Mutu Tepung}

Mutu pada tepung gadung hasil modifikasi disesuaikan dengan Standar SNI. Namun, Standar SNI khusus untuk tepung gadung belum ada. Sehingga Standar mengacu Pada SNI Tepung Mocaf, yakni SNI 7622 (2011) (Badan Standarisasi Nasional, 2011). Analisis parameter kimia menggunakan metode sebagai berikut : analisis kandar air (SNI 01-2891-1992), analisis kadar abu (923.03 AOAC 1998; SNI 01-2891-1992), dan analisis kadar HCN (SNI 6989.77:2011).

\section{HASIL DAN PEMBAHASAN}

\section{Pengaruh Waktu Perendaman Terhadap Kadar HCN}

Melalui proses perendaman, $\mathrm{HCN}$ akan larut dan berikatan dengan $\mathrm{Ca}$ dari larutan kapur. Kemudian akan terbentuk $\mathrm{Ca}(\mathrm{CN})_{2}$ yang bersifat larut dalam air dengan mudah. Pada proses perendaman, akan terjadi proses difusi $\mathrm{HCN}$ yang terdifusi keluar dari sel dan akan terserap dan terlarut ke bahan penyerap (Hardjo, 2005). Selain itu, Winarno (2004) mengatakan bahwa perendaman dengan air dapat merombak atau menguraikan HCN dari ikatan glikosida sianogenik, sehingga HCN banyak yang larut dan terbawa oleh air. Pada saat perendaman air juga terjadi proses difusi dan osmosis. Difusi pada saat perendaman terjadi dengan larutnya sisa zat yang ada pada irisan umbi gadung. Hal ini ditandai dengan kondisi air yang berubah warna atau berbuih.

Berdasarkan Gambar 1. pada perendaman selama 6 jam terjadi penurunan kadar HCN sebesar $3.73 \%$. Sementara pada perendaman selama 12 jam terjadi penurunan kadar HCN sebesar $51.01 \%$. Namun pada waktu perendaman selama 6 jam tidak terjadi perbedaan yang signifikan. Hal ini disebabkan tidak semua senyawa glukosida sianogenik terdegradasi menjadi $\mathrm{HCN}$, sehingga sebagian masih dalam bentuk aglikon dan glukosa. Hidrolisis aglikon akan membentuk senyawa HCN can keton/aldehid (Djaafar et al., 2009). Sebagian HCN yang terbentuk akan larut dalam air dan bahan penyerap, namun sebagian masih terdapat dalam irisan umbi gadung dalam beberapa jam setelah perendaman awal dilakukan, sehingga tidak menyebabkan penurunan yang signifikan yaitu dari 62.6570 ppm ke 60.3179 ppm.

Penurunan kadar HCN tertinggi yakni sebesar $56.03 \%$, pada perendaman dengan waktu tertinggi, selama 24 jam. Semakin lamanya waktu perendaman dalam air dan pelarut, senyawasenyawa yang $\mathrm{HCN}$ yang masih berada didalam irisan umbi gadung akan terdifusi keluar (Djaafar et al., 2009). Hal ini disebabkan karena terjadi pengendoran-pengendoran ikatan jaringan maka senyawa racun maupun senyawa lainya akan keluar dari selnya (Sari \& Astili, 2018). Sehingga dipilihlah variable waktu perendaman terlama $(24$ jam) untuk digunakan dalam penentuan tahapan selanjutnya.

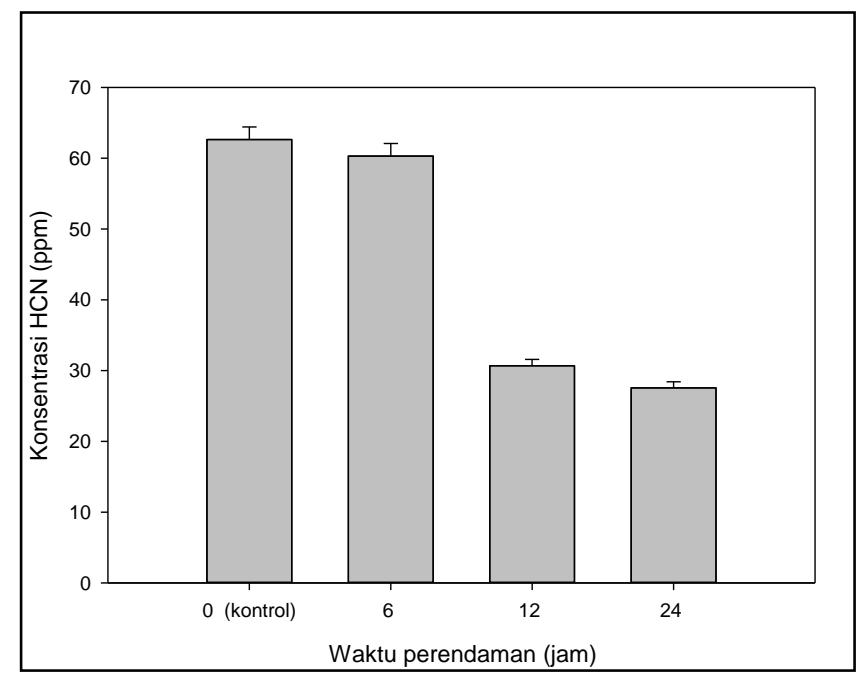

Gambar 1. Variasi Pengaruh Waktu Perendaman Terhadap Konsentrasi HCN 


\section{Pengaruh Konsentrasi Larutan Perendam Terhadap Konsentrasi HCN}

Pengaruh variasi konsentrasi larutan kapur terhadap penurunan kadar HCN menunjukan hasil yang signifikan. Dalam Gambar 2. dapat dilihat bahwa semakin tinggi konsentrasi kapur yang ditambahkan maka akan semakin signifikan pula tingkat penurunan HCN. Pada perendaman dengan konsentrasi larutan kapur 5\% terjadi penurunan kadar $\mathrm{HCN}$ sebesar $56.03 \%$. Sementara pada perendaman dengan konsentrasi larutan kapur 10\% terjadi penurunan kadar $\mathrm{HCN}$ sebesar $68.74 \%$. Penurunan kadar HCN tertinggi yakni sebesar $84.15 \%$, pada perendaman dengan konsentrasi larutan kapur $15 \%$. Semakin meningkatnya konsentrasi larutan kapur maka akan semakin banyak ion $\mathrm{Ca}^{2+}$ yang berikatan membentuk $\mathrm{Ca}(\mathrm{CN})_{2}$ sehingga semakin berkurang kadar $\mathrm{HCN}$ dalam umbi gadung.

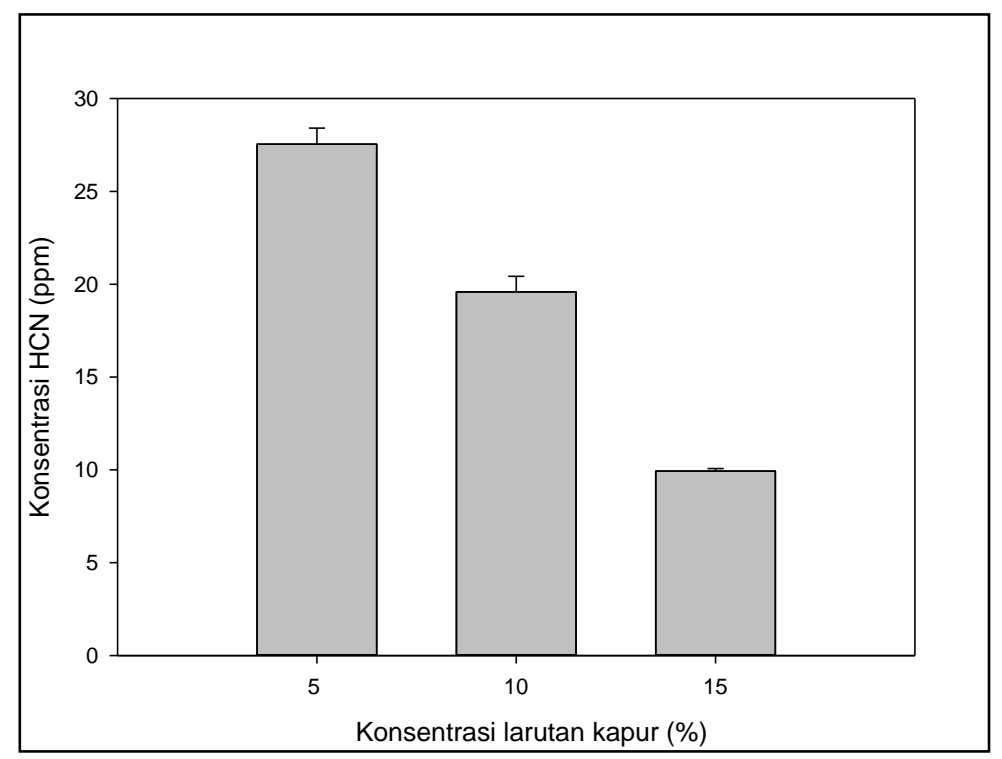

Gambar 2. Variasi Konsentrasi Kapur Terhadap Kadar HCN

Larutan kapur atau kalsium hidroksida, $\mathrm{Ca}(\mathrm{OH})_{2}$, akan terurai dalam air menjadi ion $\mathrm{Ca}^{2+}$ dan $(\mathrm{OH})^{-}$yang bersifat seperti magnet. $\mathrm{H}^{+}$dan $\mathrm{CN}^{-}$. Larutan kapur merupakan basa kuat yang dapat menurunkan $\mathrm{pH}$ (Indrawati \& Jenny Ratnawaty, 2017) dan menyebabkan plasmolisis pada membran sel umbi gadung akibat kekurangan air (Rusli et al., 2019). Asam sianida yang telah keluar dari membran sel umbi gadung akan terurai menjadi ion $\mathrm{H}^{+}$dan $\mathrm{CN}^{-}$. Kemudian asam sianida akan berikatan dengan kapur atau $\mathrm{Ca}(\mathrm{OH})_{2}$ membentuk $\mathrm{Ca}(\mathrm{CN})_{2}$ (endapan putih kalsium sianida yang mudah larut dalam air) dan menyebabkan berkurangnya asam sianida dalam umbi gadung. Reaksi antara senyawa $\mathrm{HCN}$ dan kapur atau $\mathrm{Ca}(\mathrm{OH})_{2}$ sebagai berikut:

$$
2 \mathrm{HCN}+\mathrm{Ca}(\mathrm{OH})_{2} \quad \rightarrow \quad \mathrm{Ca}(\mathrm{CN})_{2}+2 \mathrm{H}_{2} \mathrm{O}
$$

\section{Pengaruh Jenis Larutan Perendam Terhadap Konsentrasi HCN}

Pada variable penelitian ini dilakukan perbandingan pengaruh jenis larutan penyerap HCN dengan menggunakan waktu dan konsentrasi terbaik. Dapat dilihat pada Gambar 3. bahwa penggunaan kapur dengan konsetrasi $15 \%$ memiliki pengaruh yang paling signifikan (kadar HCN mencapai $9.93 \mathrm{ppm})$. Hal ini dikarenakan, kapur atau $\mathrm{Ca}(\mathrm{OH})_{2}$ dapat berfungsi merusak dinding sel dan menaikan $\mathrm{pH}$ (basa) yang ada sehingga dinding sel pecah (Djaafar et al., 2009).

Selain menggunakan kapur sebagai bahan penyerap, abu gosok juga digunakan dalam penelitian ini. Abu gosok yang digunakan dalam penelitian ini merupakan sisa pembakaran sekam padi. Unsur basa kuat dalam sekam adalah Ca. Asam sianida akan bereaksi dengan basa kuat pada abu sekam menghasilkan $\mathrm{Ca}(\mathrm{CN})_{2}$ yang bersifat mudah larut dalam air. Kemudian senyawa sianida dalam umbi gadung akan menurut Alma'arif et al., (2012). Sehingga reaksi yang terjadi dapat dituliskan sebagai berikut : 


$$
\begin{gathered}
\mathrm{Ca}_{2}{ }^{+}+\mathrm{O}_{2} \rightarrow \mathrm{CaO} \\
\mathrm{CaO}+2 \mathrm{HCN} \rightarrow \mathrm{Ca}(\mathrm{CN})_{2}+\mathrm{H}_{2} \mathrm{O}
\end{gathered}
$$

Penurunan kadar HCN pada perendaman dengan larutan kapur lebih signifkan daripada perendaman dengan larutan abu gosok ataupun dengan campuran keduanya. Pada kapur maupun abu gosok (sekam) mengandung unsur $\mathrm{Ca}$. Unsur $\mathrm{Ca}$ ini yang berikatan dengan $\mathrm{CN}$ dengan reaksi $\mathrm{CaO}+2 \mathrm{HCN} \rightarrow \mathrm{Ca}(\mathrm{CN})_{2}+\mathrm{H}_{2} \mathrm{O}$ membentuk garam $\mathrm{Ca}(\mathrm{CN})^{2}$ dan air. Namun, terdapat perbedaan konsentrasi Ca yang cukup signifikan pada kapur dan abu gosok. Menurut Noviyanti et al., (2015) kapur mengandung Ca sebesar 85 \%, sementara menurut Alma'arif et al., (2012) pada abu gosok mengandung $\mathrm{Ca}$ hanya sebesar $0.139 \%$. Adanya perbedaan kandungan $\mathrm{Ca}$ yang jauh lebih tinggi pada kapur teresebut menjadikan perendaman dengan larutan kapur menjadi lebih efektif karena dapat lebih banyak mengikat molekul sianida.

Penelitian ini juga dapat menunjukkan penurunan $\mathrm{HCN}$ yang berimbang dengan penelitian penurunan umbi gadung dengan metode feremntasi yang dilakukan oleh Widiyanti \& Kumoro (2017). Setelah proses fermentasi selama 120 jam, terjadi penurunan kadar HCN sebesar $87.84 \%$. Namun, waktu perlakuan perendaman pada penelitian ini lebih cepat 96 jam dibandingkan dengan metode fermentasi yang dilakukan oleh peneliti terdahulu. Selain itu penelitian ini lebih hemat energi dibandingkan dengan metode penelitian menggunakan pemanasan. Syafi et al., (2009) melakukan pemanasan (suhu $50^{\circ} \mathrm{C}$ ) pada irisan umbi gadung selama $12 \mathrm{jam}$. Terjadi penurunan kadar sianida dari $469,50 \mathrm{mg} / \mathrm{kg}$ menjadi $53,43 \mathrm{mg} / \mathrm{kg}$. Kadar HCN terendah pada penelitian ini yakni $9.93 \mathrm{ppm}$. Menurut FAO, standar batas HCN yakni dibawah 10 ppm pada bahan pangan (Sasongko, 2009).

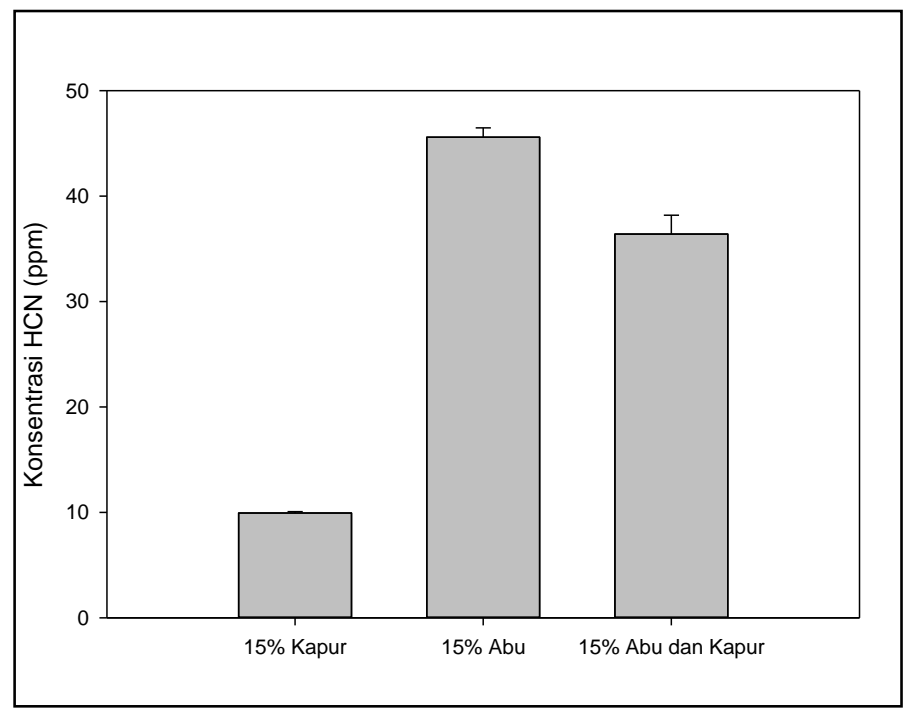

Gambar 3. Waktu dan Konsetrasi Terbaik dengan Menggunakan Beragam Variasi Bahan Penyerap $\mathrm{HCN}$

\section{Parameter Kimia dan Parameter Fisik Produk Tepung Gadung}

Tepung gadung yang telah dilakukan perendaman, pencucian, pengeringan dan penepungan selanjutnya akan dikarakterisasi. Karakterisasi produk tepung gadung dilakukan dalam bentuk parameter kimia (uji proximate dan uji kadar sianida) dan parameter fisik. Adapun standar tepung yang digunakan mengacu pendekatan pada SNI tepung komersil yakni tepung Mocaf. Adapun parameter kimia pada tepung hasil penelitian dan referensi dapat dilihat pada Tabel 1. 
Tabel 1. Parameter Kimia Tepung Hasil Penelitian dan SNI 7622 Tahun 2011

\begin{tabular}{|c|c|c|c|c|c|c|c|}
\hline \multirow{2}{*}{ Jenis } & \multicolumn{5}{|c|}{ Parameter Proximate (\%) } & \multirow{2}{*}{$\begin{array}{c}\text { Kadar } \\
\text { HCN (ppm) }\end{array}$} & \multirow{2}{*}{ Referensi } \\
\hline & Protein & Lemak & Karbohidrat & Abu & Air & & \\
\hline $\begin{array}{l}\text { Tepung gadung } \\
\text { kering (tanpa } \\
\text { perlakuan) }\end{array}$ & 4.89 & 2.7 & 78.03 & 2.55 & 11.83 & 62.66 & $\begin{array}{l}\text { Penelitian } \\
\text { ini }\end{array}$ \\
\hline $\begin{array}{c}\text { Tepung gadung } \\
\text { kering (perlakuan*) }\end{array}$ & 4.00 & 0.30 & 78.61 & 6.01 & 11.08 & 9.93 & $\begin{array}{c}\text { Penelitian } \\
\text { ini }\end{array}$ \\
\hline Tepung komersil & - & - & - & $\begin{array}{c}\text { Maks. } \\
1,5\end{array}$ & $\begin{array}{l}\text { Maks. } \\
13\end{array}$ & Maks. 10 & $\begin{array}{c}\text { SNI 7622 } \\
\text { (2011) dan } \\
\text { Sasongko } \\
(2009)\end{array}$ \\
\hline
\end{tabular}

Keterangan : perlakuan* : perendaman dengan larutan kapur 15\%)

Pada Tabel 1. Parameter kimia pada tepung gadung kering hasil perlakuan pada penelitian menghasilkan tepung dengan kadar HCN yang sesuai standard dan layak dikonsumsi (SNI 7622, 2011). Selain itu, proses pengeringan setelah perendaman menghasilkan kadar air yang rendah sesuai standar. Dengan kadar air yang rendah dapat meningkatkan masa simpan dari tepung umbi gadung (Mujumdar \& Law, 2010). Parameter proximate lain yang dijadikan Standar SNI adalah kadar abu. Pada penelitian ini, kadar abu belum memenuhi standar dan cenderung meningkat apabila dibandingkan dengan tepung gadung kering tanpa perlakuan. Hal ini terkait dengan proses perendaman dengan larutan kapur yang meningkatkan kadar zat anorganic pada produk.

Tabel 2. Parameter Fisik Tepung Hasil Penelitian dan SNI 7622 (2011)

\begin{tabular}{ccc}
\hline Kriteria Uji & Satuan & Persyaratan \\
\hline & Parameter Fisik (Uji Organoleptik) & \\
\hline Bentuk & - & Serbuk Halus \\
\hline Bau & - & Normal \\
\hline Warna & - & Putih \\
\hline
\end{tabular}

Parameter fisik berdasarkan (Badan Standarisasi Nasional, 2011) SNI 7622 (2011) meliputi bentuk, bau, dan warna (lihat Tabel 2). Setelah proses pengeringan, umbi gadung kering melewati proses grinding dan shieving sehingga didapatkan tepung dengan bentuk serbuk halus berukuran 80 mesh. Kemudian dilanjutkan pengujian secara organoleptik pada bau dan warna. Bau dari tepung umbi gadung berbau normal dan warnanya putih, dapat dilihat pada Gambar 4. Secara keseluruhan, berdasarkan pengujian organoleptic maka tepung umbi gadung hasil penelitian telah memenuhi SNI dari teprung komersil, yakni SNI 7622 (2011).

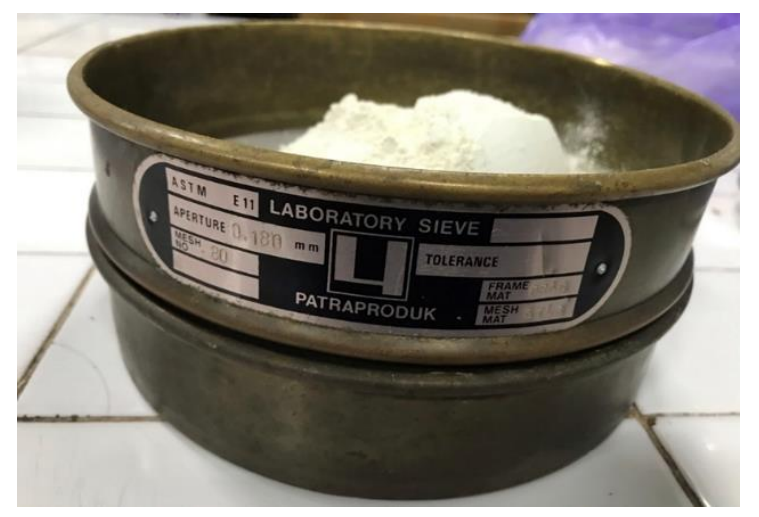

Gambar 4. Tepung Umbi Gadung Hasil Penelitian 


\section{SIMPULAN}

Pada penelitian ini dilakukan variasi waktu perendaman umbi gadung selama 6, 12 dan 24 jam. Hasil terbaik diperoleh pada proses perendaman selama 24 jam. Selain itu variasi konsentrasipun dengan bahan penyerap kapur juga dilakukan dengan penggunaan variasi $5 \%, 10 \%$ dan $15 \%$. Kondisi operasi terbaik pada penelitian ini dengan menggunakan jenis bahan penyerap berupa kapur dengan konsentrasi 15\% dibandingkan penggunaan bahan abu gosok $15 \%$ maupun campuran abu gosok dengan kapur $15 \%$. Penurunan kadar HCN tertinggi yakni sebesar $84.15 \%$, pada perendaman dengan konsentrasi larutan kapur $15 \%$.

Gadung yang telah dilakukan perendaman, pencucian, pengeringan dan penepungan selanjutnya akan dikarakterisasi. Standar tepung yang akan diacu merupakan pendekatan daripada SNI dai tepung mokaf yakni SNI 7622 tahun 2011. Dari beberapa parameter standard SNI yang sudah ditetapkan yaitu abu, air dan kadar HCN yang hanya tidak memenuhi standar hanya abu. Hal ini terkait dengan proses perendaman dengan larutan kapur yang meningkatkan kadar zat anorganic pada produk. Standar SNI juga menetapkan parameter fisik (uji organoleptik) pengujian secara organoleptik pada bau dan warna. Bau dari tepung umbi gadung berbau normal dan warnanya putih. Berdasarkan pengujian organoleptic maka tepung umbi gadung hasil penelitian telah memenuhi SNI dari teprung komersil, yakni SNI 7622 tahun 2011.

\section{DAFTAR PUSTAKA}

Alma'arif, A. L., Wijaya, A., \& Murwowono, D. (2012). PENGHILANGAN RACUN ASAM SIANIDA ( $\mathrm{HCN}$ ) DALAM UMBI GADUNG DENGAN MENGGUNAKAN BAHAN PENYERAP ABU. Jurnal Teknologi Kimia Dan Industri, 1(1), 14-20.

AOAC. (1990). AOAC Official Methods of Analysis. Association of Official Agricultural Chemists. Washington, D.C., 15th(Volume 1), 136-138.

Apriansyah D, Hadi Suprapto, \& Deny Sumarna. (2014). Pengaruh Perendaman Umbi Gadung Dayak dalam Air, Larutan Garam, dan Larutan Kapur terhadap Kandungan Asam Sianida Selama Enam Hari Perendaman. Jurnal Teknologi Pertanian, 9(2), 49-52.

Badan Standardisasi Nasional (BSN). (1992). Standar Nasional Indonesia. SNI 01-2891. Cara Uji Makanan dan Minuman.

Badan Standarisasi Nasional. (2011). Tepung Mokaf SNI No.7622:2011.

Cahyo Kumoro, A., Susetyo Retnowati, D., \& Sri Budiyati, C. (2011). Removal of Cyanides from Gadung (Dioscorea hispida Dennst.) Tuber Chips using Leaching and Steaming Techniques. Journal of Applied Sciences Research, 7(12), 2140-2146.

Djaafar T F, Siti Rahayu, \& Murdijati Gardjito. (2009). Pengaruh blanching dan waktu perendaman dalam larutan Kapur terhadap kandungan racun pada umbi dan ceriping gadung. Penelitian Pertanian Tanaman Pangan, 28(3), 192-198. http://pangan.litbang.pertanian.go.id/files/10pp032009.pdf

Hardjo, M. (2005). Tepung Gadung (Dioscorea Hispida DENNST) Bebas Sianida dengan Merendam Parutan Umbi dalam Larutan Garam. Matematika, Sains, Dan Teknologi, 6(2), 92-99.

Indrawati, R., \& Jenny Ratnawaty, G. (2017). Pengaruh Perendaman Larutan Kapur Sirih terhadap Kadar Asam Sianida pada Biji Karet. Jurnal Laboratorium Khatulistiwa, 1(1), 58. https://doi.org/10.30602/jlk.v1i1.98

Luthfi, A., Wijaya, A., Murwono, I. R. P. D., Kimia, J. T., Teknik, F., Diponegoro, U., Sudharto, J. P., \& Fax, T. (2012). Gadung Dengan Menggunakan Bahan Penyerap Abu. Jurnal Teknologi Kimia Dan Industri, 1(1), 14-20.

Mujumdar, A. S., \& Law, C. L. (2010). Drying Technology: Trends and Applications in Postharvest Processing. Food and Bioprocess Technology, 3(6), 843-852. https://doi.org/10.1007/s11947-0100353-1

Noviyanti, Jasruddin, \& Sujiono, E. H. (2015). KARAKTERISASI KALSIUM KARBONAT $(\mathrm{Ca}(\mathrm{CO} 3))$ DARI BATU KAPUR KELURAHAN TELLU LIMPOE KECAMATAN SUPPA. Jurnal Sains Dan Pendidikan Fisika, 11(2), 169-172.

Pramitha, A. R., \& Wulan, S. N. (2017). Detoxification of Cyanide in Gadung Tuber (Dioscorea Hispida dennst.) by a combination Soaking in Ash Suspension and Boiling. Jurnal Pangan Dan Agroindustri, 5(2), 58-65.

Pratiwi, R. S. (2016). Pemanfaatan Umbi Uwi Dan Umbi Gadung Sebagai Alternatif Media Potato Dextrose Agar (PDA) Untuk Pertumbuhan Jamur. 23(45), 5-24. 
Rusli, S., Tamrin, \& Hermanto. (2019). PENGARUH PERENDAMAN DALAM BERBAGAI KONSENTRASI LARUTAN KAPUR DAN GARAM TERHADAP PENURUNAN KADAR ASAM SIANIDA ( HCN ) UMBI GADUNG ( Dioscorea hispida Dennst ). Jurnal Sains Dan Teknologi Pangan, 4(6), 2647-2657.

Sari, Fi. D. N., \& Astili, R. (2018). Kandungan Asam Sianida Dendeng dari Limbah Kulit Singkong. Jurnal Dunia Gizi, 1(1), 20. https://doi.org/10.33085/jdg.v1i1.2899

Sasongko, P. (2009). Detoksifikasi Umbi Gadung (Dioscorea hispida dennst.) melalui Proses Fermentasi Menggunakan Kapang Mucor sp. Jurnal Teknologi Pertanian, 10(3), 205-215.

Widiyanti, M., \& Cahyo Kumoro, A. (2017). Kinetika Detoksifikasi Umbi Gadung (Dioscorea hispida dennst.) Secara Fermentasi dengan Kapang Mucor racemosus. Reaktor, 17(2), 81-88. https://doi.org/10.14710/reaktor.17.2.81-88

Winarno, F. G. (2004). Kimia Pangan dan Gizi. PT Gamedia Pustaka Utama.

Wulandari, C. A., Hersoelistyorini, W., \& Nurhidajah. (2017). Pembuatan Tepung Gadung (Dioscorea hispida DENNST) Melalui Proses Perendaman Menggunakan Ekstrak Kubis Fermentasi. Prosiding Seminar Nasional Publikasi Hasil-Hasil Penelitian Dan Pengabdian Masyarakat, September, 423-430. 